
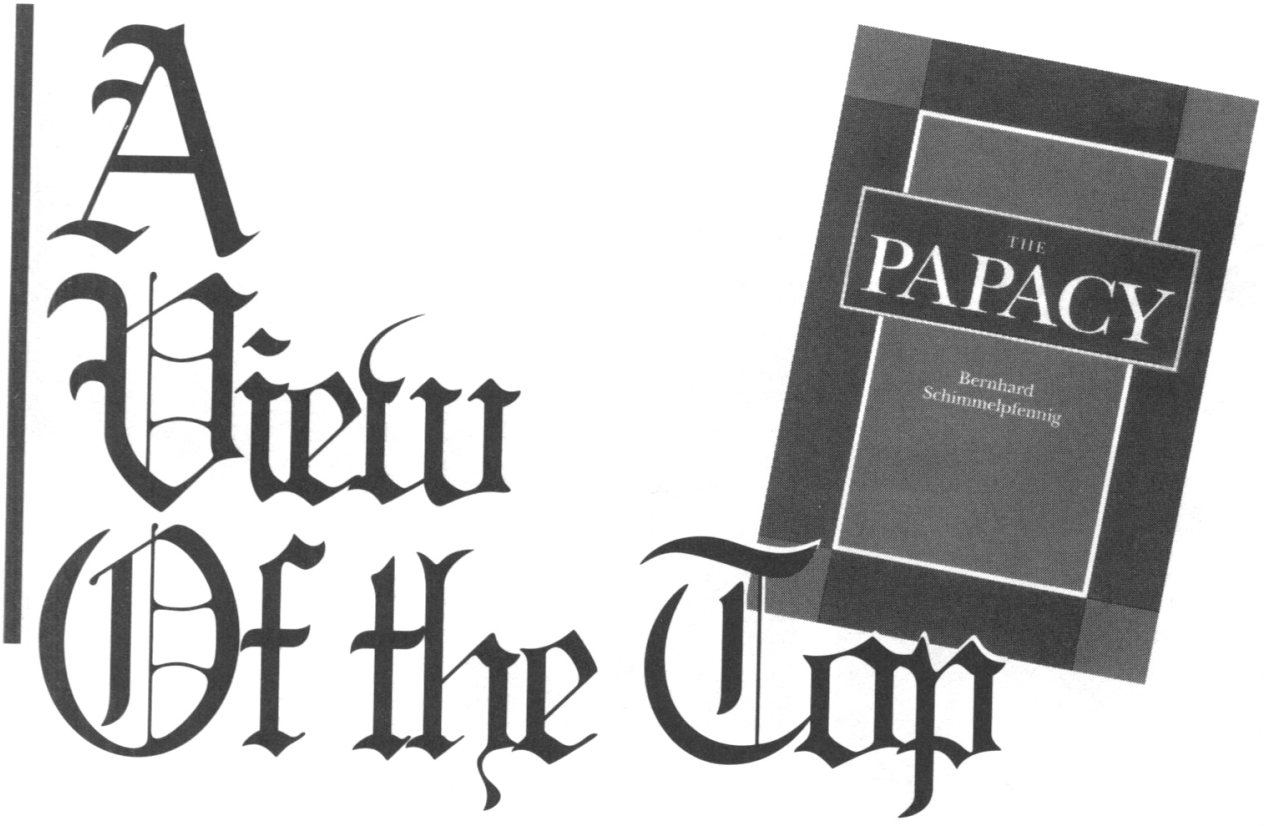

\title{
THE PAPACY
}

\section{Bernhard Schimmelpfennig transloted by James Sievert}

Whereas previous books on this subject have dealt only with individual popes, The Papacy is a unique history of the institution of the papacy.

Schimmelpfennig addresses the evolution of the liturgical and political character of the Catholic Church from the Roman Empire to the Middle Ages. Topics also discussed are the significance of Rome as the physical setting of the Vatican, and the degree to which papal power was able to form the city around it.

"The book is as learned as it is delightful to read-a pleasure for the general reader as well as for the scholar who will appreciate both Schimmelpfennig's wit and style and the well-selected bibliography."

-UTA-RENATE BLUMENTHAL, THE CATHOLIC UNIVERSITY OF AMERICA

288 pp., \$20.00 paper, \$60.00 eloth

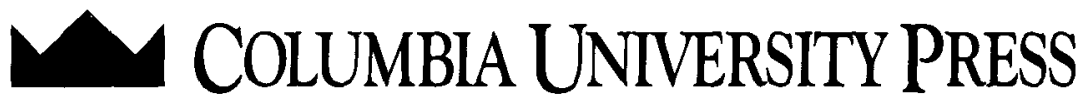




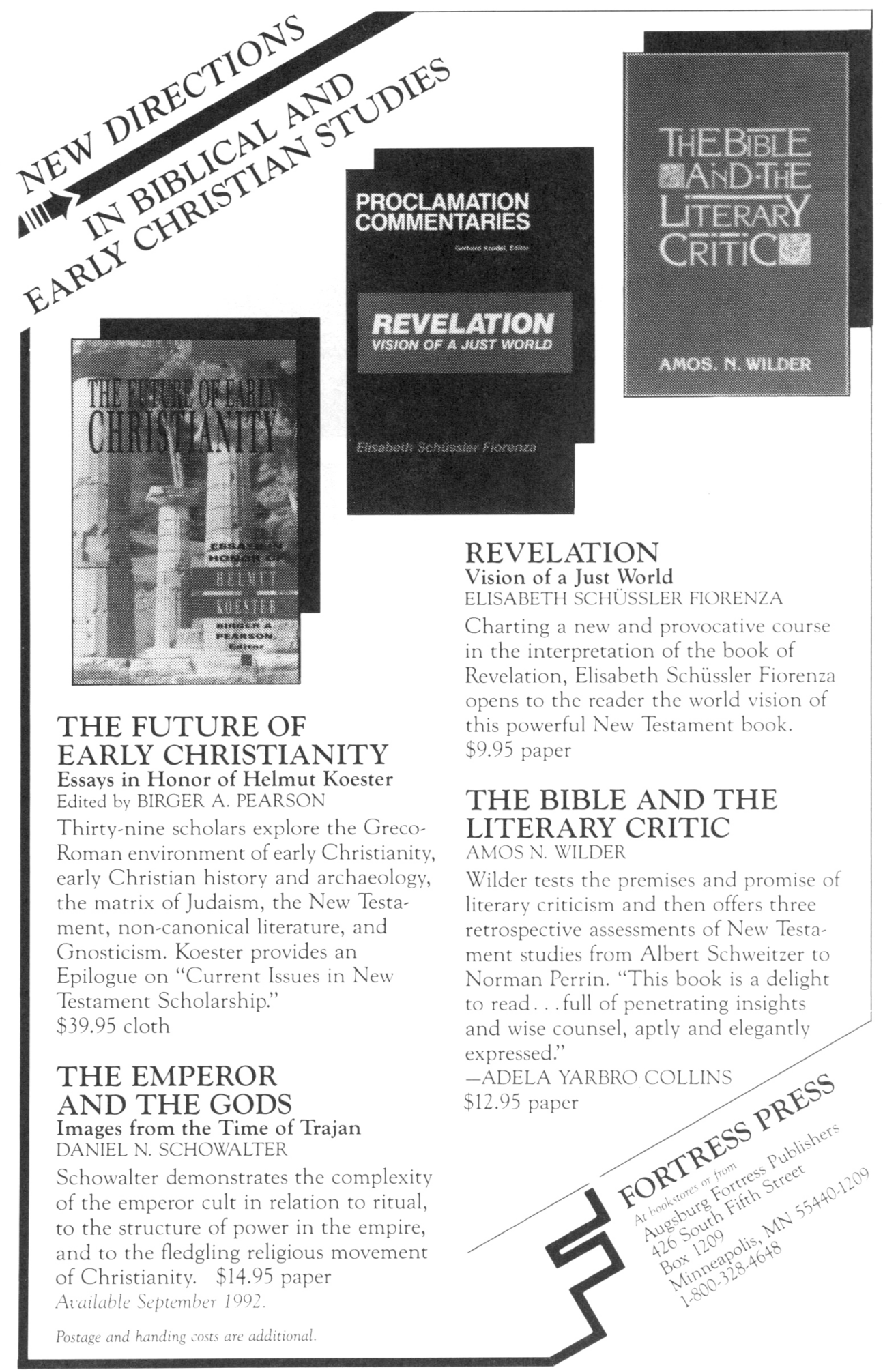




\section{5:1 JANUARY 1992}

1 The Story of Dinah in the Testament of Levi James Kugel

35 Athenagoras the Christian, Pausanias the Travel Guide, and a Mysterious Corinthian Girl Louis A. Ruprecht, Jr.

51 The Interest in Life of Jesus Theology as a Paradigm for the Social History of Biblical Criticism Dieter Georgi

85 Kant's "Appropriation" of Lampe's God Stephen Palmquist

109 God and the World: William Paley's Argument from Perfection Tradition-A Continuing Influence John T. Baldwin

121 Books Received 